\title{
Effects of Climate Change on the Production and Profitability of Cassava in the Niger Delta Region of Nigeria
}

\author{
J. O. Ajayi
}

Department of Agricultural and Resource Economics, Federal University of Technology, Akure, Nigeria

\begin{abstract}
Nigeria is the single largest producer of cassava in the world with the bulk of the cassava coming out from the Niger Delta region. Human, economic and agricultural activities are currently threatened in the region by vagaries in climatic factors. These vagaries affect the production and profitability of cassava. The study was therefore conducted to assess the effects of climate change on the production and profitability of cassava in the Niger Delta region of Nigeria. The study made use of a multi-stage sampling technique to select three hundred and sixty respondents across the three highest cassava-producing states (Awka Ibom, Cross Rivers and Ondo) in the region. Data for the study were collected with the aid of well-structured questionnaires assisted with interview schedules. Data collected were analysed using descriptive statistics and regression model. The determinants of cassava profitability were farm size, farmers' experience in cassava cultivation, farmers' experience in adopting climate change coping strategies, number of climate change coping strategies adopted, costs of input materials in Naira and labour cost in Naira.
\end{abstract}

\section{Keywords:}

Climate change, cassava, production, profitability, Niger Delta .

\section{Introduction}

Nigeria is the world's largest producer of cassava with other top producers being Indonesia, Thailand, the Democratic republic of Congo and Angola. In the year 2010, Nigeria's production of cassava reached 37.5 million tonnes (Asante-Pok, 2013). The Nigerian Government facilitated the development of new disease-resistant cassava varieties by the joint efforts of International Institute for Tropical Agriculture (IITA), National Root Crops Research Institute (NRCRI), Root and Tuber Expansion Program (RTEP), and the Federal Ministry of Agriculture, in conjunction with State Agricultural Development Programs and cassava farmers.

The Presidential Initiative on Cassava, launched in 2003, brought cassava to the national limelight. The Initiative had as its goal the promotion of cassava as a viable foreign exchange earner and also the development of the production system to sustain the national demand. The Presidential Initiative focused its intervention on the development of production, processing, and marketing of the processed products (Sanni et al., 2009).
Cassava production in the Niger Delta region of Nigeria

Cassava as a crop originated from South America and it is extensively propagated as an annual crop in the tropical and sub-tropical regions for its edible starchy tuber as root. It is an annual crop that may often be left longer than 12 months and usually planted as a sole crop or in combination with other crops. Production is all year round activity and it does well in a warm, moist climate. Cassava is very tolerant and has the ability to grow on marginal land where other food crops cannot grow well, but for its high yield and productivity moderate climatic condition and best soil properties like a light, sandy loamy soil of medium fertility and good aerations or drainage are all crucial (Akanbi, Olabode, 2004). Hence, extreme weather conditions such as prolonged drought and excessive amount of rainfall that leads into flood may be detrimental to cassava outputs and critically affect its productivity.

Key traditional cassava products in the Niger Delta region of Nigeria

Traditional cassava products in the Niger Delta region include gari, lafun, fufun and apu. Gari is 
the most consumed and marketed of all cassava food products both within and outside the region. Gari is a partly gelatinised, roasted, free flowing granular flour with a slightly fermented flavor, creamy-white (or yellow, if from yellow-fleshed roots or fortified with red palm oil). Lafun is flour from fermented dried cassava that is later made into a stiff paste and eaten with sauce. Apu is a variant of lafun popularly consumed by people from Ondo State. A granular product made from partly gelatinised cassava starch, is also known as tapioca.

Key industrial cassava products in the Niger Delta region of Nigeria

High quality cassava flour (HQCF) is a major intermediate product. Development of HQCF is a key success in cassava processing, as it became the means to scale up industrial utilisation in the Niger Delta region and across Nigeria. The flour is being used either alone or as a composite in bakery products. Before this, Nigeria used to import over one million tonne of wheat annually. In the 1990s, after the depreciation of the naira, the high cost of wheat almost sent bakers out of business, thus compelling them to look for an alternative. To face this challenge, IITA developed a simple and appropriate process for producing HQCF that is suitable for baking. This was tested in the baking and confectionary industries; it was found successful and the cost implications were favorable (Sanni et al., 2009).

Cassava starch is used as an ingredient in manufactured foods (infant foods, confectionary, glucose, alcohol) and in non- food industries (glues, oil well drilling, adhesives, paper sizing and bonding, textile sizing and strengthening). It is also widely used as a thickening agent in soup and for laundry purposes. The traditional starch is used for clothes or consumed at a local level in the form of tapioca, often with special flavors (vanilla, banana). Some NGOs are encouraging this form of utilization as an income-generating activity as the product can be sold at weekly or seasonal village markets (Sanni et al., 2009).

Dried (split) roots are the cheapest form of storable cassava. They are typically popular in transitional and savanna areas where sun drying is relatively easier than in forest zones. Peeled roots or chips are often slightly molded or fermented to a certain degree, according to climatic conditions, local taste, and consumption habits. They are milled or pounded into (fermented) flour that does not comply with standards for replacing wheat. The fermentation alters the sensory characteristics of the roots in a way that is often appreciated by local consumers (Sanni et al., 2009).

\section{Climate change in the Niger Delta of Nigeria}

Basically, climatic condition as predetermined by the weather pattern and its elements over a long period of between 30 to 40 years is known as climate. This is different from weather which is the atmospheric condition within a very short period of time of at most two weeks. The classical period as determined by the World Meteorological Organization is 30 years which a number of changes in the variables that determine the predominant climatic pattern in the regions are known. The climatic elements include rainfall, temperature, sunshine intensity, relative humidity, atmospheric pressure, cloud cover, snow, dew, frost and wind (Ezekiel et al., 2012)

Human activities have exacerbated climate change with its attendant impacts on agriculture in many communities in the Niger Delta region. Marine resources, fisheries, forest resources and crop production and productivity may not be spared from the effects of vagaries in climatic factors. Climate change also affects livelihood vulnerability (Bryceson et al., 2002, Cochrane, 2006, Ekins et al., 2003, Reed et al., 2013). Terrestrial water and carbon cycles also respond to climate change and variability through a set of coupled physical and physiological processes (Raupach, 2013), Social-ecological system collapse is also possible (Roser, 2001, Richter, 2013)

Global and regional climate changes are affecting all economic sectors to some degrees. Agricultural sector is perhaps the most sensitive and vulnerable. This is because agricultural production remains very dependent on climatic resources. Researches have revealed that that the earth is likely to warm by $0.2^{\circ} \mathrm{C}$ per decade for the next two decades and to rise between $0.60 \mathrm{C}$ and $4.0^{\circ} \mathrm{C}$ by the end of the century depending on future emissions. The resultant effects of this is that climate variability will impact food production in several ways (Ezekiel et al, 2012).

Agriculture in the Niger Delta is largely raindependent as irrigation is seldom practiced. Nzeadibe et al. (2011) further noted that changes in the rainfall pattern have greatly affected vegetation and agriculture in the region. Cassava 
remains key to the food economy of the people of the Niger Delta region. As majority of the people living in the Niger Delta are farmers, the environmental and social consequences of climate change is putting livelihoods at serious risks.

Although notable researches have been conducted in the region on climate change which include environmental degradation, vulnerability and mitigation of climate change impacts (Akinro et al., 2008), coastal management and adaptation to climate change (Etuonovbe, 2008), and Awareness of climate change and implications for achieving the MDGs in the Niger Delta region of Nigeria (Ajayi, 2014). However, there is literature dearth on researches on the effects of climate change on the production and profitability of cassava in the Niger Delta region. This necessitated this research work.

This research therefore attempts to answer such questions as what effects does climate change has on the production and profitability of cassava in the study area? What are the coping strategies to climate change effects in the study area and what are the determinants of profitability of cassava production in the study area? The study of the effects of climate change on the production and profitability of cassava in the Niger Delta region of Nigeria was therefore conducted with the following objectives which include to:

i. Examine the effects of climate change on the production and profitability of cassava in the study area.

ii. Investigate the coping strategies to climate change effects on the production and profitability of cassava in the study area and

iii. Examine the determinants of profitability of cassava production in the study area

\section{Materials and methods}

\section{The study area}

The area of this study is the Niger Delta region of Nigeria. The Niger Delta, as defined officially by the Nigerian government, covers about $70,000 \mathrm{~km}^{2}$ of marshland, creeks, tributaries and lagoons that drain the Niger River into the Atlantic at the Bight of Biafra and makes up $7.5 \%$ of Nigeria's land mass consistingof the nine states of Abia, Akwa- Ibom, Bayelsa, Cross-River, Delta, Edo, Imo, Ondo and Rivers (Mba, Ogbuagu, 2013, Ajayi, 2014). The region is reputed for having diverse vegetation belts: from the largest rain forests in Nigeria to mangrove swamps, savannahs, mountains and waterfalls with rare animals, including endangered species and unusual plant families, making it one of the World's richest biodiversity centres attracting scientists and tourists. The region had a population of 31.2 million people at 2006 census (Ajayi, 2014) with more than 40 ethnic groups including the Bini, Efik, Ibibio, Annang, Oron, Ijaw, Itsekiri, Isoko, Urhobo, Ukwuani, and Kalabari, are among the inhabitants in the Niger Delta, speaking about 250 different dialects, the bulk of which lives in rural fishing and farming communities (Ajayi, 2014). Common crops popularly grown in the region include cassava, cocoyam, white yam, maize, garden egg, pepper, okra, melon, fruited pumpkin and oil palm (Mmom, 2009). Among these, oil palm and cassava remain the leaders in the food economy of the region while cassava is most diversely useful crop in the region serving as raw material to traditional and industrial food processors within and beyond the region.

\section{Sampling technique, size and data collection}

A multistage sampling technique was used for this study. In the first stage, three states of Akwa Ibom, Cross Rivers and Ondo were purposively selected from the nine (9) states that make up the Niger Delta region in Nigeria, being the highest cassavaproducing states in the Niger Delta. In the second stage, using the delineation by the three (3) states' Agricultural Development Programmes (ADPs), two (2) cassava-producing Local Government Areas (LGAs) were randomly selected from each state giving total of six (6) cassava-producing LGAs. In the third stage, from each of the selected LGAs, two blocks were randomly selected for study. This gave a total of twelve (12) blocks. Initially, residents from the selected blocks were invited to a community forum at which a preliminary identification of different categories of cassava farmers was carried out. At the community forum, fifteen (15) cassava famers made up of males, females and youths who constituted the focus group were purposively selected from the list of those identified and discussions were held with them. During the community forum, using Focus Group Discussion (FGD), and Key Informant Interviews 
(KII) with the help of community leaders, a sampling frame of all cassava farmers was built up in each community. From this list, random samples of 30 cassava farmers were selected and interviewed using semi-structured interview schedules thus making a total sum of 360 cassava farmers from the study area.

\section{Data collection}

Rapid Rural Appraisal (RRA) (transect walks, identification and inspection of farm lands) was as data collection method. The RRA used had the advantage of encouraging the respondents to describe their relationship with their natural resources. The RRA also had the advantage of identifying of variables of importance to the cassava farmers and in the formulation of questions that were included in the more formal semi- structured interview schedule in locally meaningful terms. Two single gender Focus Group Discussions (FGDs), one for men and another for women were held with farmers in each state with number of participants ranging from 10-20. The resultant six FGDs were very helpful in eliciting clearer information from the respondents.

\section{Data analysis}

Descriptive statistics and regression model were used in the data analysis. The descriptive statistics used included means, percentages, frequencies and tables. The effects of climate change on cassava production in the study area was measured on three-point Likert-type scale of "high" (3), "moderate" (2) and "low". Climate change effects with mean scores of $\geq 2.5$ were regarded "high", effects with mean responses from 1.5 to 2.49 were regarded "moderate" while those with mean less than 1.5 were regarded as "low". Also, the use of coping strategies for climate change in the study was measured on a three-point Likerttype scale of "always" (3), "rarely" (2) and "not at all". Coping strategies with mean scores of $\geq 2.5$ were regarded "highly adopted", strategies with mean responses from 1.5 to 2.49 were regarded "adequately adopted" while those with mean less than 1.5 were regarded as "poorly adopted. Multiple regression analysis was used to isolate factors determining the profitability of cassava production as taken prosy by net farm income. The implicit form of the regression model is presented as:

$$
Y=f\left(X_{1}, X_{2}, X_{3}, X_{4}, X_{5}, X_{6} \ldots \ldots X_{11}, e\right)
$$

Where, $Y=$ Net farm income (profitability in Naira)

$X_{1}=$ age of cassava farmers

$X_{2}=$ sex of cassava farmers

$X_{3}=$ education of cassava farmers

$X_{4}=$ farm size (in hectares)

$X_{5}=$ fousehold size

$X_{6}=$ farmers experience in cassava cultivation

$X_{7}=$ farmers experience in adopting climate change coping strategies

$X_{8}=$ number of climate change coping strategies adopted

$X_{9}=$ cost of input materials (in Naira)

$X_{10}=$ cost of labour (in Naira)

$X_{11}=$ variety of cassava cultivated

$e=$ error term

Three functional forms of the regression model were fitted to the data collected and the best fit was selected based on established criteria. The a priori expectation was that the coefficients of the independent variables should be greater than zero.

\section{Results and discussion}

Effects of climate change on cassava productivity in the study area

From the analysis of the respondents' perceived effects of climate change on cassava production in the study area as shown in Table 1 , it is now very evident that climate change has effects on the cassava productivity in the Niger Delta region of Nigeria. These effects are responsible for the dwindling cassava production figures in Nigeria. Should the effects be adequately checked with necessary coping strategies by cassava farmers and policy makers, the present productivity of cassava in the Niger Delta region will improve and by extension snowball Nigeria into greater heights in cassava production and marketing providing more food, employment opportunities and foreign exchange for the nation in the global market should more international markets be created for the crop.

Coping strategies to the effects of climate change on cassava production in the study area

From the analysis of the respondents' coping strategies to the effects of climate change on cassava production in the study area as shown in Table 2, 


\begin{tabular}{|l|r|r|r|r|r|r|r|l|l|}
\hline Effects of climate change on cassava & \multicolumn{1}{|c|}{ High } & \multicolumn{1}{|c|}{ Moderate } & \multicolumn{1}{l|}{ Low } & \multicolumn{1}{|c|}{ High } & Moderate & Low & Mean & Remarks \\
\hline & \multicolumn{3}{|c|}{ Frequency } & \multicolumn{3}{|c|}{ Percentage (\%) } & & \\
\hline High subseptivity to pests and diseases & 240 & 80 & 40 & 66.67 & 22.22 & 11.11 & 2.56 & High \\
\hline Runof of soil nutrients due erosion & 178 & 99 & 83 & 49.44 & 27.5 & 23.06 & 2.26 & Moderate \\
\hline Increased weed population & 54 & 70 & 236 & 15 & 19.44 & 65.56 & 1.49 & Low \\
\hline $\begin{array}{l}\text { Inadequate water supply/drought for } \\
\text { nutrient circulation }\end{array}$ & 211 & 127 & 22 & 58.61 & 35.28 & 6.11 & 2.52 & High \\
\hline Late maturing of cassava roots & 165 & 145 & 50 & 45.83 & 40.28 & 13.89 & 2.32 & Moderate \\
\hline High temperature destroying soil nutrients & 134 & 139 & 87 & 37.22 & 38.61 & 24.17 & 2.13 & Moderate \\
\hline Discoloration of cassava leaves & 254 & 89 & 17 & 70.56 & 24.72 & 4.722 & 2.66 & High \\
\hline Discoloration of cassava roots & 267 & 27 & 66 & 74.17 & 7.5 & 18.33 & 2.56 & High \\
\hline Reduced cassava roots & 221 & 116 & 23 & 61.39 & 32.22 & 6.39 & 2.55 & High \\
\hline Reduced dry matter of cassava roots & 67 & 26 & 267 & 18.61 & 7.22 & 74.17 & 1.44 & Low \\
\hline Reduced starch content of cassava roots & 178 & 81 & 101 & 49.44 & 22.5 & 28.06 & 2.21 & Moderate \\
\hline Reduced water content of cassava roots & 194 & 78 & 88 & 53.89 & 21.67 & 24.44 & 2.29 & Moderate \\
\hline Stunted growth of cassava plants & 213 & 122 & 25 & 59.17 & 33.89 & 6.944 & 2.52 & High \\
\hline
\end{tabular}

Source: Computed from field survey, 2014

Table 1: Effects of climate change on cassava production in the study area.

\begin{tabular}{|l|c|c|c|c|c|c|c|c|c|c|}
\hline Coping strategies & Always & \multicolumn{1}{|c|}{ Rarely } & Not at all & \multicolumn{1}{|c|}{ Always } & Rarely & Not at all & Mean & Remarks \\
\hline Early and late planting & \multicolumn{3}{|c|}{ Frequency } & \multicolumn{2}{|c|}{ Percentage (\%) } & & \\
\hline Soil and water conservation & 187 & 90 & 40 & 63.89 & 25.00 & 11.11 & 2.42 & $\mathrm{~A}$ \\
\hline Use of organic manures & 213 & 83 & 64 & 59.17 & 23.06 & 17.77 & 2.51 & $\mathrm{H}$ \\
\hline Use of inorganic fertilizer & 211 & 117 & 32 & 58.61 & 32.50 & 8.89 & 2.41 & $\mathrm{~A}$ \\
\hline $\begin{array}{l}\text { Planting pest and disease } \\
\text { resistant cassava cuttings }\end{array}$ & 187 & 103 & 70 & 51.94 & 28.61 & 19.44 & 2.38 & $\mathrm{~A}$ \\
\hline $\begin{array}{l}\text { Use of cassava cuttings that are } \\
\text { well acclimated }\end{array}$ & 134 & 129 & 97 & 37.22 & 35.83 & 26.94 & 1.99 & $\mathrm{~A}$ \\
\hline $\begin{array}{l}\text { Draining of wetland for } \\
\text { cassava cultivation }\end{array}$ & 122 & 120 & 118 & 33.89 & 33.33 & 32.78 & 1.86 & $\mathrm{~A}$ \\
\hline $\begin{array}{l}\text { Making of contour bund } \\
\text { around farmland }\end{array}$ & 67 & 26 & 267 & 18.61 & 7.22 & 74.17 & 2.10 & $\mathrm{~A}$ \\
\hline Planting of trees & 101 & 81 & 178 & 28.05 & 22.5 & 49.44 & 2.50 & $\mathrm{H}$ \\
\hline $\begin{array}{l}\text { Minimum tillage system (zero/ } \\
\text { minimum) }\end{array}$ & 184 & 78 & 98 & 51.11 & 21.67 & 27.22 & 2.28 & $\mathrm{~A}$ \\
\hline $\begin{array}{l}\text { Use of irrigation system/water } \\
\text { storage }\end{array}$ & 79 & 89 & 192 & 21.94 & 24.72 & 53.33 & 1.89 & $\mathrm{~A}$ \\
\hline Reforestation/ Afforestation & 99 & 114 & 147 & 27.50 & 31.67 & 40.83 & 1.83 & $\mathrm{~A}$ \\
\hline $\begin{array}{l}\text { Use of chemicals like } \\
\text { herbicide, insecticide }\end{array}$ & 187 & 111 & 62 & 51.94 & 30.83 & 17.22 & 2.49 & $\mathrm{~A}$ \\
\hline Increase in number of weeding & 123 & 145 & 92 & 34.17 & 40.28 & 25.56 & 2.54 & $\mathrm{H}$ \\
\hline $\begin{array}{l}\text { Use of early maturing cassava } \\
\text { varieties }\end{array}$ & 165 & 105 & 90 & 45.83 & 29.17 & 25.00 & 2.48 & $\mathrm{~A}$ \\
\hline $\begin{array}{l}\text { Protection of water sheds } \\
\text { and mulching }\end{array}$ & 89 & 66 & 205 & 24.72 & 18.33 & 56.94 & 2.51 & $\mathrm{H}$ \\
\hline $\begin{array}{l}\text { Preservation of cassava } \\
\text { cuttings for planting }\end{array}$ & 212 & 92 & 56 & 58.89 & 25.56 & 15.56 & 2.51 & $\mathrm{H}$ \\
\hline
\end{tabular}

Source: Computed from field survey, 2014

Table 2: Coping strategies to the effects of climate change on cassava production - beginning. 


\begin{tabular}{|c|c|c|c|c|c|c|c|c|}
\hline \multirow[t]{2}{*}{ Coping strategies } & Always & Rarely & Not at all & Always & Rarely & Not at all & \multirow[t]{2}{*}{ Mean } & \multirow[t]{2}{*}{ Remarks } \\
\hline & \multicolumn{3}{|c|}{ Frequency } & \multicolumn{3}{|c|}{ Percentage $(\%)$} & & \\
\hline $\begin{array}{l}\text { Use of weather-resistant } \\
\text { cassava variety }\end{array}$ & 180 & 90 & 90 & 50.00 & 25.00 & 25.00 & 2.11 & A \\
\hline $\begin{array}{l}\text { Reducing access to eroded/ } \\
\text { erosion prone area }\end{array}$ & 231 & 89 & 40 & 64.17 & 24.72 & 11.11 & 2.60 & A \\
\hline Mixed cropping practices & 197 & 67 & 96 & 54.72 & 18.61 & 26.67 & 2.24 & A \\
\hline $\begin{array}{l}\text { Use of recommended planting } \\
\text { distance }\end{array}$ & 267 & 76 & 21 & 74.17 & 21.11 & 5.83 & 2.36 & A \\
\hline $\begin{array}{l}\text { Changing the timing of land } \\
\text { preparation }\end{array}$ & 193 & 90 & 77 & 53.61 & 25.00 & 21.39 & 2.33 & A \\
\hline Changing harvesting dates & 201 & 90 & 69 & 55.83 & 25.00 & 19.17 & 2.27 & A \\
\hline $\begin{array}{l}\text { Out migration from climate } \\
\text { risk areas }\end{array}$ & 79 & 67 & 216 & 21.94 & 18.61 & 60.00 & 2.48 & A \\
\hline Use of windbreaks/shelter belts & 207 & 90 & 63 & 57.50 & 25.00 & 17.50 & 2.63 & $\mathrm{H}$ \\
\hline
\end{tabular}

Source: Computed from field survey, 2014

Table 2: Coping strategies to the effects of climate change on cassava production - continuation.

use of organic manures; planting of trees; increase in number of weeding; protection of water sheds and mulching; preservation of cassava cuttings for planting; use of windbreaks/shelter belts were rated "high adopted" coping strategies while the reaming coping strategies were rated "averagely adopted". They include Early and late planting; soil and water conservation; use of inorganic fertilizer; planting pest and disease resistant cassava cuttings; use of cassava cuttings that are well acclimated; draining of wetland for cassava cultivation; making of contour bund around farmland; minimum tillage system (zero/ minimum); use of irrigation system/water storage; reforestation/ afforestation; Use of chemicals like herbicide, insecticide; Use of early maturing cassava varieties; use of weather-resistant cassava variety; reducing access to eroded/erosion prone area; mixed cropping practices; use of recommended planting distance; changing the timing of land preparation; changing harvesting dates and out migration from climate risk areas. Meanwhile, none of the coping strategies was poorly adopted by the respondents.

Regression results of determinants of cassava profitability in the study area

Table 3 shows the results of the regression analysis to examine the determinants of cassava profitability in the study area. The double-log functional form provided the best fit as shown in the regression model. Six of the independent variables; $X_{4}, X_{6}, X_{7}$, $X_{8}, X_{9}$ and $\mathrm{X}_{10}$ were significant at 5\% level (i.e. $95 \%$ confidence interval). These variables were farm size, farmers' experience in cassava cultivation, farmers' experience in adopting climate change coping strategies, number of climate change coping strategies adopted, cost of input materials and cost of labour. The parameter estimates of each of these variables also carried signs, which conformed to a priori expectations. The results indicate that farm size, farmers' experience in cassava cultivation, farmers' experience in adopting climate change coping strategies, number of climate change coping strategies adopted positively influenced cassava net farm income (profitability) in the study area. Thus, the major determinants of cassava profitability were these four factors. All the explanatory variables together explained about $91 \%$ of the variations observed in cassava profitability. The positive effect of adoption of improved varieties of cassava on yield has been earlier observed by both (Dipeolu et al, 2004) and (Mafimisebi, 2005). The (CBN, 1999) also observed that adoption of improved variety was responsible for increase in production from 31 million tonnes in 1994 to 34 million tonnes in 1998 .

The regression model is therefore given as:

$$
\begin{aligned}
5.274= & f\left(-0.006 X_{1}+0.002 X_{2}+0.003 X_{3}+1.0230 X_{4}\right. \\
& +0.006 X_{5}+0.007 X_{6}+0.012 X_{7}+0.015 X_{8} \\
& \left.-0.04 X_{9}-0.046 X_{10}+0.002 X_{11}+0.01135\right)
\end{aligned}
$$




\begin{tabular}{|c|c|c|c|c|c|c|}
\hline \multirow[t]{2}{*}{ Variables } & \multicolumn{2}{|c|}{ Simple Log } & \multicolumn{2}{|c|}{ Semi-Log } & \multicolumn{2}{|c|}{ Double Log } \\
\hline & Coefficients & T-value & Coefficients & T-value & Coefficients & T-value \\
\hline Constants & $\begin{array}{c}3577.234 \\
(4725.093)\end{array}$ & 0.757 & $\begin{array}{c}807428.401 \\
(1.357)\end{array}$ & 1.357 & $\begin{array}{c}5.274 \\
(0.110)\end{array}$ & 47.772 \\
\hline$X_{I}$ & $\begin{array}{l}-60.498 \\
(34.909)\end{array}$ & -1.733 & $\begin{array}{c}-7713.567 \\
(-0.299)\end{array}$ & -0.299 & $\begin{array}{l}-0.006 \\
(0.005)\end{array}$ & -1.352 \\
\hline$X_{2}$ & $\begin{array}{c}-698.924 \\
(1014.861)\end{array}$ & -0.689 & $\begin{array}{c}1964.363 \\
0(.079)\end{array}$ & 0.079 & $\begin{array}{l}0.002 \\
(005)\end{array}$ & 0.499 \\
\hline$X_{3}$ & $\begin{array}{c}450.851 \\
(533.548)\end{array}$ & 0.845 & $\begin{array}{c}37514.570 \\
(1.862)\end{array}$ & 1.862 & $\begin{array}{c}0.003 \\
(0.004)\end{array}$ & 0.807 \\
\hline$X_{4}$ & $\begin{array}{l}134293.121 \\
(2032.285)\end{array}$ & 66.080 * & $\begin{array}{c}928356.192 \\
(7.778)\end{array}$ & $7.778^{*}$ & $\begin{array}{c}1.023 \\
(0.022)\end{array}$ & $46.216^{*}$ \\
\hline$X_{5}$ & $\begin{array}{c}406.309 \\
(203.430)\end{array}$ & $1.997^{*}$ & $\begin{array}{c}7714.022 \\
(0.409)\end{array}$ & 0.409 & $\begin{array}{c}0.006 \\
(0.003)\end{array}$ & 1.65 \\
\hline$X_{6}$ & $\begin{array}{c}61.431 \\
(52.032)\end{array}$ & 1.181 & $\begin{array}{c}12642.747 \\
(0.723)\end{array}$ & 0.723 & $\begin{array}{c}0.007 \\
(0.003)\end{array}$ & $2.150^{*}$ \\
\hline$X_{7}$ & $\begin{array}{c}-9.263 \\
(110.466)\end{array}$ & -0.084 & $\begin{array}{c}35099.513 \\
(1.292)\end{array}$ & 1.292 & $\begin{array}{c}0.012 \\
(0.005)\end{array}$ & $2.400^{*}$ \\
\hline$X_{8}$ & $\begin{array}{l}-202.327 \\
(242.199)\end{array}$ & -0.835 & $\begin{array}{c}11816.024 \\
0(.452)\end{array}$ & 0.452 & $\begin{array}{c}0.015 \\
(0.005)\end{array}$ & $3.000^{*}$ \\
\hline$X_{9}$ & $\begin{array}{l}-0.033 \\
(0.023)\end{array}$ & -1.478 & $\begin{array}{c}-73538.809 \\
(-1.018)\end{array}$ & -1.018 & $\begin{array}{l}-0.004 \\
(0.013)\end{array}$ & $-3.067 *$ \\
\hline$X_{10}$ & $\begin{array}{l}-0.011 \\
(0.021)\end{array}$ & -0.512 & $\begin{array}{c}-80388.113 \\
(-0.840)\end{array}$ & -0.84 & $\begin{array}{l}-0.046 \\
(0.018)\end{array}$ & $-2.556^{*}$ \\
\hline$X_{11}$ & $\begin{array}{c}340.086 \\
(1114.042)\end{array}$ & 0.305 & $\begin{array}{c}42773.952 \\
(1.546)\end{array}$ & 1.546 & $\begin{array}{c}0.002 \\
(0.005)\end{array}$ & 0.482 \\
\hline & $\mathrm{R} 2=0.89$ & & $\mathrm{R} 2=0.87$ & & $\mathrm{R} 2=0.91$ & \\
\hline & $\mathrm{SE}=8155.62361$ & & $\mathrm{SE}=61160.72031$ & & $\mathrm{SE}=0.01135$ & \\
\hline & F value $=22293.9$ & & $\mathrm{~F}$ value $=370.7$ & & $\mathrm{~F}$ value $=17428.7$ & \\
\hline
\end{tabular}

Note: *means significant at $5 \%$ level

Values in parenthesis are $t$ ratios

Source: Computed from field survey, 2014

Table 3: Regression results of determinants of cassava profitability in the study area.

\section{Conclusion}

The results of analysis show that high effects of climate change include high susceptibility to pests and diseases; inadequate water supply/drought for nutrient circulation; discoloration of cassava leaves; discoloration of cassava roots; reduced cassava roots and stunted growth of cassava plants while runoff of soil nutrients due erosion; late maturing of cassava roots; high temperature destroying soil nutrients; reduced starch content of cassava roots and reduced water content of cassava roots were "moderate" effects; increased weed population and reduced dry matter of cassava roots were of "low" effects. It is also needful to say that all the coping strategies to climate change effects on cassava productivity in by the farmers were either highly or averagely adopted with none being poorly adopted. This emphasizes the farmers' awareness level and commitment to prevent cassava production which is their economic source of living from the effects of climate change. The study further revealed that the determinants of cassava profitability were farm size, farmers' experience in cassava cultivation, farmers' experience in adopting climate change coping strategies, number of climate change coping strategies adopted, cost of input materials and cost of labour.

The study therefore recommends that more coping 
strategies should be adopted while encouraging high adoption of the strategies which have not been highly adopted. These should be done in search of new innovations for reducing climate change effects on cassava production and profitability in the study area. Also, combination and experience in several coping strategies have been found to reduce effects of climate change on cassava production with improved net farm income to cassava production in the study area.

Corresponding author:

Joseph Omotoso Ajayi

Department of Agricultural and Resource Economics, Federal University of Technology, P.M.B 704, Akure, Ondo State, Nigeria

Phone: +2348060743135, E-mail: josephomotosoajayi@yahoo.com

\section{References}

[1] Ajayi, J. O. Awareness of climate change and implications for attaining the Millennium Development Goals (MDGs) in Niger Delta Region of Nigeria, Agris on-line Papers in Economics and Informatics, 2014, Vol. 4, No 1, p. 3-11. ISSN 1804-1930.

[2] Akanbi, W. B., Olabode, O. S., Olaniyi, J. O., Ojo, A. O. Introduction to Tropical Crops. Published by Raflink Compter Eleyele, Ibadan, 2004.

[3] Akinro, A. O., Opeyemi, D. A., Ologunagba, I. B. Climate Change and Environmental Degradation in the Niger Delta Region of Nigeria: Its vulnerability, impacts and possible mitigations. Research Journal of Applied Sciences, 2008, Vol.,3, No.,3, p. 167-173. (Online) ISSN 1993-6079.

[4] Asante-Pok, A. Analysis of incentives and disincentives for cassava in Nigeria. Technical notes series, 2013, MAFAP, FAO, Rome.

[5] Bryceson, D. F. The Scramble in Africa: re-orienting rural livelihoods. World Development, 2002, Vol. 30, No 5, p. 725-739. ISSN 0305-750X.

[6] CBN. Statistical Bulletin and Statement of Accounts. Central Bank of Nigeria, Abuja. 1999.

[7] Cochrane, P. Exploring cultural capital and its importance in sustainable development. Ecological Economics. 2006, Vol. 57, p. 318-330. ISSN 0921-8009.

[8] Dipeolu, A. O., Ayinde, I. A., Adebayo, K., Oyewole, O. B., Sanni, L. O., Pearce, D. M., Wandschneider, T. S., White, J. L.,Westby, A. Viability Analysis of Cassava Processing in South West of Nigeria. Report submitted to the Department for International Development (DFID), Crop Harvest Research Programme (Project R7495), U.K. 2000.

[9] Ekins, P., Simon, S., Deutsch, L., Folke, C., De Groot, R. A framework for the practical application of the concepts of critical natural capital and strong sustainability. Ecological Economics. 2003, Vol. 44, p. 165-185. ISSN 0921-8009.

[10] Etuonovbe, A. K. Sustaining coastal Management/Adaptation of climatic change and sea level rise in the Niger Delta. Paper presented at Integrating Generations FIG Working, Week 2008 Stockholm, Sweden 14-19 June 2008. [Online] Available: http://www.fig.net/pub/fig2008/papers/ ts03f/ts03f_06_etuonovbe_2753.pdf. [Accessed 25 Novebmber 2014].

[11] Ezekiel, A. A., Olawuyi, S. O., Ganiyu, M. O., Ojedokun, I. K., Adeyemo, S. A. Effects of Climate Change on Cassava Productivity in Ilesa - East Local Government Area, Osun State, Nigeria, British Journal of Arts and Social Sciences. 2012, Vol. 10, No. 2. ISSN: 2046-9578.

[12] Mafimisebi, T. E. Determinants and uses of farm income from the cassava enterprise in Ondo State, Nigeria, Journal of Human Ecology, 2008, Vol. 24, No 2, p. 125-130. ISSN 0970-9274. 
[13] Mba, P. N., Ogbuagu, R. A. Environmental and socio-economic impact of oil exploration in the Niger Delta region: a case study of Ibeno, Nigeria. Journal of Economics and Sustainable Development. 2012, Vol. 3, No. 9, p. 97-103. ISSN 2222-1700.

[14] Mmom, C. Impact of Poverty and changing Cropping Systems on Agro-crop diversity in the upper Niger Delta, Nigeria. Impact Assessment and Human Well-Being 29th Annual Conference of the International Association for Impact Assessment, 16-22 May 2009, Accra International Conference Center, Accra, Ghana.

[15] Nzeadibe, T. C., Ajaero, C. K. Assessment of socio-economic characteristics and quality of life expectations in rural communities of Enugu State, Nigeria. Applied Research in Quality of Life, 2010, Vol. 5, No. 4, p. 353- 371. ISSN:1871-2584, E-ISSN:1871-2576.

[16] Odoemenem, I. U., Otaanwa, L. B. Economic Analysis of Cassava Production in Benue State, Nigeria, Current Research Journal of Social Sciences. 2011, Vol. 3(5), p. 406-411. ISSN 2041-3246.

[17] Raupach, M. R., Haverd, V., Briggs, P. R. Sensitivities of the Australian terrestrial water and carbon balances to climate change and variability. Agricultural and Forest Meteorology. 2013, p. 227-291. ISSN 0168-1923.

[18] Reed, M. S., Podesta G., Fazey, I., Geeson, N., Hessel, R., Hubacek, K., Letson, D., Nainggolan, D., Prell, C., Rickenbach, M. G., Ritsema, C., Schwilch, G., Stringer, L. C., Thomas, A. D. Combining analytical frameworks to assess livelihood vulnerability to climate change and analyse adaptation options. Ecological Economics. 2013, Vol. 94, p.66-77. ISSN 0921-8009.

[19] Richter, A., Soest, D., Grasman, J. Contagious cooperation, temptation, and ecosystem collapse. Journal of Environmental Economics and Management. 2013, Vol. 66, p. 141-158, ISSN 0095 0696.

[20] Rosser, J. B. Complex ecologic-economic dynamics and environmental policy, Ecological Economics. 2001, Vol. 37, p. 23-37. ISSN 0921-8009.

[21] Sanni, L., Onadipe, O. O., P. Ilona, P., Mussagy, M. D., Abass, A., Dixon, A. G. O. Successes and challenges of cassava enterprises in West Africa: a case study of Nigeria, Bénin, and Sierra Leone. IITA, Ibadan, Nigeria, 2009. p. 19. 